\title{
A holistic approach to the assessment of the groundwater destructive effects on stone decay in Edfu temple using AAS, SEM-EDX and XRD
}

\author{
M. A. El-Gohary ${ }^{1}$
}

Received: 1 April 2015/ Accepted: 17 July 2015/Published online: 18 December 2015

(c) The Author(s) 2015. This article is published with open access at Springerlink.com

\begin{abstract}
The objective of this study is to investigate the groundwater influences on sandstone in Horus temple, in addition to studying the deterioration processes affecting the temple building materials. Specific investigations were carried out to measure the groundwater features and quality both inside and outside the temple to evaluate the resulted deterioration processes. Our results argue that the temple was built on a hill of silt and clay belonging to the Cretaceous Era; it rises on the south part of the Nile valley far from the Nile for about $1200 \mathrm{~m}$. Groundwater quality is strongly influenced by the dominating minerals and stone aquifer affected by three major water sources. The temple faces many deterioration processes due to the effect of groundwater characterized by high salinity index. These processes led finally to two main mechanisms, (the first related to micro-deterioration and the second resulting from structural defects). These mechanisms affirmed that the stone building materials were highly characterized by weakness, fracture, disintegration, cracks and crevices collapsing of their components. Furthermore, the dominating major salt species are halite, gypsum, sylvite and thenardite and minor quantities of carbonates and bi-carbonates, in addition to phosphate as or trace constituents.
\end{abstract}

Keywords Deterioration - Groundwater - Salt - TDS . EC $\cdot$ Cations $\cdot$ Anions

M. A. El-Gohary

m_1968_algohary@yahoo.com

1 Conservation Department, Sohag University, Sohag 82524, Egypt

\section{Introduction}

Deterioration processes, which have to go on for many years before showing apparent damage, are to be monitored over relatively short time intervals or when such processes are simulated in the laboratory. Thus, it is critical to ascertain the parameters that control deterioration and the operative decay processes, with an ultimate goal of mitigating potential deterioration, especially in wet environment (Cardell et al. 2008). Stone decay takes many different forms, sometimes the stone weathers away gradually; other times large scales of stone drop away in one go. The surface may erupt into blisters or the stone may lose all integrity. Many factors contribute to the decay of the stone, which can be regarded as the sum of processes that affect rocks and give rise to new products and structures that are more stable under the surface environments. All these processes are controlled by three main factors: rock (chemical composition and physical properties) (Montoto 2000), nature of the solutions present (e.g. ions/molecules, concentrations, ionic force, acidity, etc.) (El-Gohary 2011), and environment (e.g. temperature, organic matter, drainage, etc.) (Molina Ballesteros et al. 2010). Rising damp is a widespread phenomenon and a major cause of decay to masonry materials especially when coupled with high salt concentrations. It can cause several deterioration forms even when it is mild. Saline groundwater is considered the most important factor that may affect the extent of damage to different materials and lead to several deterioration forms according to its quality "chemical composition". Groundwater quality largely depends on the mineralogical composition, physical properties of rocks, anthropogenic activities, and biogeochemical processes, in addition to mineral weathering through rock-water interaction and percolated water (Kim 2002). It 
also depends on the duration of contact with the aquifer chemical constituents and the nature of recharge water. These processes generally dominate the concentration of the major cations ( $\mathrm{Ca}, \mathrm{Mg}, \mathrm{Na}$ and $\mathrm{K}$ ) in groundwater (Kim et al. 2005).

In Egypt, groundwater is considered the major factor contributing to the deterioration of the Pharaonic monuments through salt weathering (El-Gohary 2012). This phenomenon is one of the most serious problems resulting from rising damp; it is widely recognized as one of the primary deterioration agents of archaeological buildings, objects and all historical structures. Salt weathering is a threshold phenomenon that leads to one outcome type before the effect (alternative hydration and crystallization cycles) and another type after it (full disintegration mechanisms and forms), furthermore, the behaviour of salt within the stone buildings is not straightforward (Turkington and Smith 2000). Within the same context, there are wide range of analytical techniques which may be used for explaining materials deterioration depending on the type of information needed. Atomic Absorption Spectroscopy (AAS) technique has been applied to analyze the sample's chemistry because it has a number of features which make it particularly appropriate to such analysis (Hughes et al. 1976). Furthermore, it can determine a wide range of elements, concentrations in parts per million provided by quite accurate results even with quite small samples compared to other techniques (Beaty and Kerber 1993). Scanning Electron Microscopy coupled with Energy Dispersive X-ray Spectroscopy (SEM-EDX) is a powerful tool used to investigate the material surfaces, and gives useful information about the specimen micro-structure (Cardell et al. 2002), with high resolution. It has good focus over a wide range of specimen surfaces and can provide high-quality imaging facilities (Freestone and Middleton 1987). Moreover, X-Ray Diffraction (XRD) is an important technique for characterizing the crystal composition; it is used to identify and quantify the soluble salts present in soluble salt solution sample such as sodium sulfate phase (Linnow 2007). The main objective of this study is to find out different causes of deterioration factors and their mechanisms affecting the building masonry in Horus temple through different effects of ground water. These effects produce many micro-deterioration forms and structural problems. Therefore, all the obtained data about moisture, salt load, hygroscopic effects, stone properties and their changes in deteriorated zones, have to be put together and discussed and finally, to obtain the scientific basis for decisions about appropriate restoration measurements.

\section{Brief historical overview of Horus temple}

The Temple of Horus (Fig. 1a) was dedicated to the falcon headed God Horus (Fig. 1b) (Baines and Malek 2000). It was built during the reign of six ptolemies. The construction of this temple was begun in 237 BC. By Ptolemy III (Evergetes I) and was finished in 57 BC by Ptolemy XII (Auletes). Work on the temple continued throughout this period with a brief interruption of 20 years because of the riot during the period of Ptolemy IV (Philopator) and Ptolemy V (Epiphanies). The temple is not only the best preserved ancient temple in Egypt, but it is also the second largest after Karnak Temple. It was believed that the temple was built on the site of the great battle between the two famous gods in this area, Horus and Set. Hence, the current temple was the last one in a long series of temples built in this location; the pylons of the main temple are about 118 feet high, with typical scenes of the pharaoh in the battle with his enemies. Within the pylons is the colonnaded courtyard, with distinctive pared columns, which leads to the great hypostyle hall. On the other side of the courtyard, there are gates, which lead to an area behind the temple and inside the building walls.
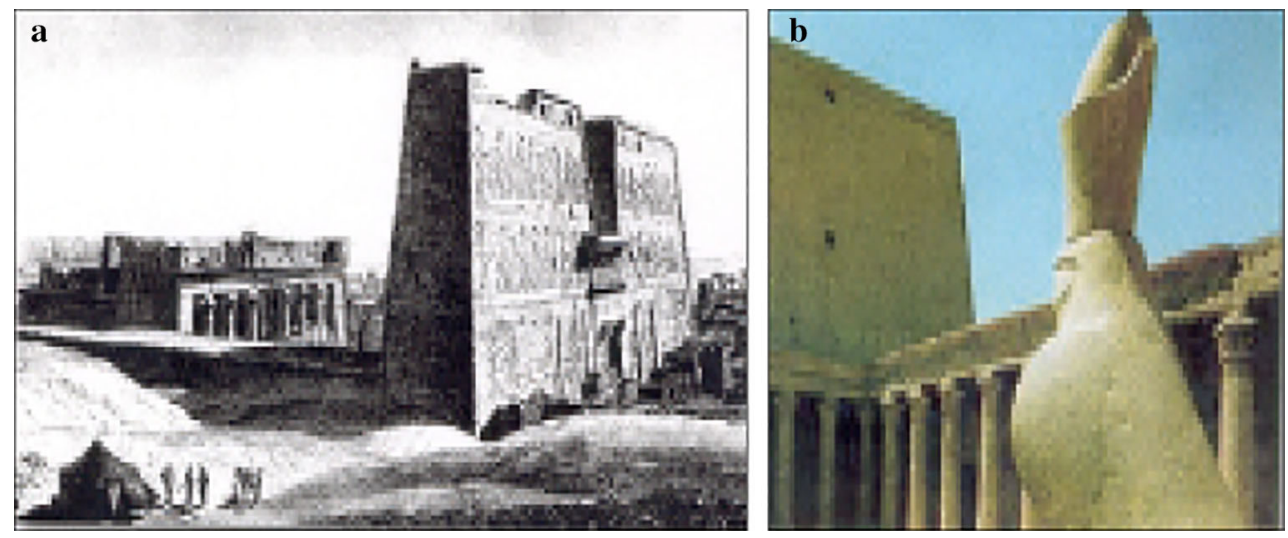

Fig. 1 a The temple of Horus in Edfu, b the falcon headed god Horus 
Fig. 2 a Geographic location and topographic features of Edfu temple, b schematic map of Edfu temple and surrounded area
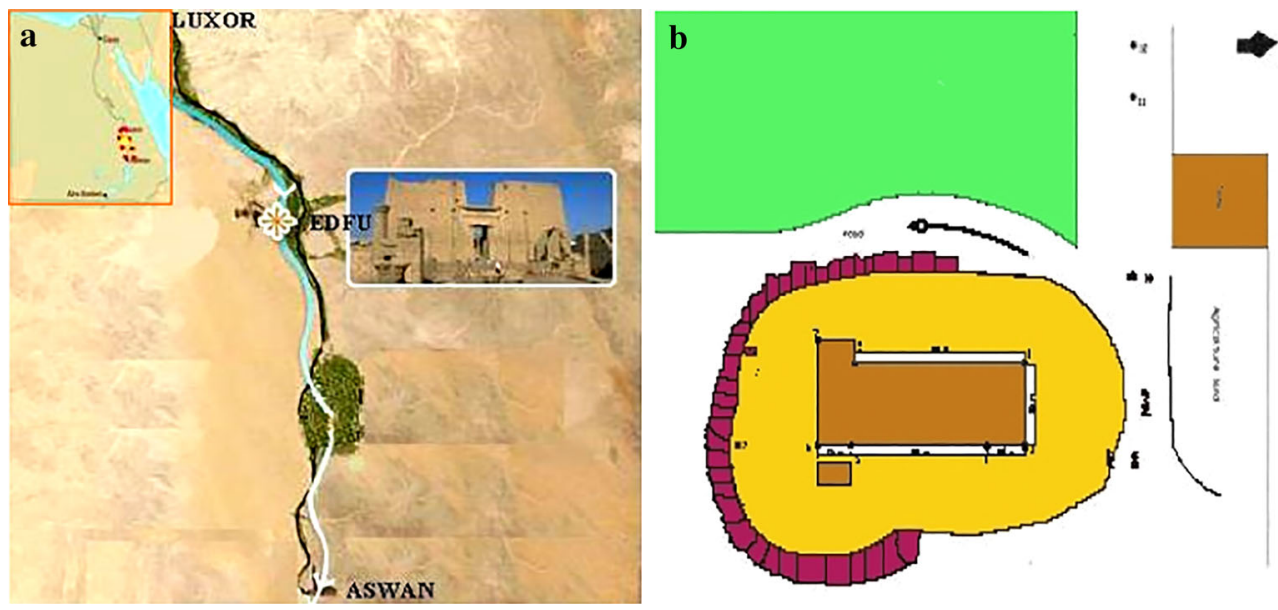

\section{Geographic location, topographic features and geological framework}

Edfu town, Fig. 2a is $120 \mathrm{~km}$ from Aswan governorate and is located on its northern part. The temple area is located on the western part of Edfu town, on the border between the cultivated land and the old town. Practical fieldworks, measurements and cadastral maps proved that the temple is surrounded, from the eastern, northern and southern parts by recent buildings which rise about $5.8 \mathrm{~m}$. from the land of the temple. The temple (Fig. 2b) was built on a hill of silt and clay belonging to the Cretaceous period. From the western part, the temple borders are cultivated whose level parallels the level of the temple. According to Senosy et al. (1998), the study area is located on the alluvial plains of the Nile Valley, which are surrounded by structural plateaus capped by Eocene limestone and underlain by Paleocene shale. These plains slope gently to the north and east and they could be differentiated into other older plain structures. Through the main geological studies about this region, four major stratigraphic formations have been recognized. They are: Edfu formation, Esna shale, Armant formation and finally Issawia formation. The structural units to which the area understudy belongs is the stable shelf which covers the Northern part of Egypt, which is considered a part of a large belt surrounded by ill-defined boundaries from the Arabo-Nubian massif.

\section{Stratigraphic scheme and hydrogeological system}

Through field study and analyzing the stratigraphic obtained data, it could be noted that the temple rises on the south part of the Nile valley coming from Aswan to Qena, $1200 \mathrm{~m}$ far from the Nile. So, it is localized inside the Stable Shelf structural unit. Inside this geological unit, the Nubia sandstone and shales are capped by shelly limestone and bone beds of Campaniano to the Mastrichtian age. The
Table 1 a typical stratigraphic section in the Nile valley between Aswan to Qena

\begin{tabular}{|c|c|c|}
\hline No. & Lithological formation & $\begin{array}{l}\text { Thickness } \\
\text { (m) }\end{array}$ \\
\hline 1 & $\begin{array}{l}\text { Hard-oyster limestone, cherty in part with } \\
\text { Ostrea villei }\end{array}$ & $\sim 2$ \\
\hline 2 & Thinly-bedded shaley & $\sim 10$ \\
\hline 3 & Hard ferruginous bone and coprolite bed & $\sim 1$ \\
\hline 4 & $\begin{array}{l}\text { Grey laminated shales with vertebrate } \\
\text { remains }\end{array}$ & $\sim 12$ \\
\hline 5 & $\begin{array}{l}\text { Yellow-weathering flaggy sandstone, } \\
\text { occasionally ripple-marked with shale } \\
\text { partings containing plant remains }\end{array}$ & $\sim 16$ \\
\hline 6 & $\begin{array}{l}\text { Iron-stained grayish-green and blackish } \\
\text { gypseous shale with ferruginous } \\
\text { concretions and bands of shale with } \\
\text { plant remains }\end{array}$ & $\sim 22$ \\
\hline 7 & $\begin{array}{l}\text { Hard brown sandstone with occasional } \\
\text { shale casts }\end{array}$ & $\sim 2$ \\
\hline 8 & $\begin{array}{l}\text { Iron-stained fissile shale with plant } \\
\text { remains }\end{array}$ & $\sim 8$ \\
\hline 9 & $\begin{array}{l}\text { Ripple-marked flaggy shale sandstone, } \\
\text { forming ledge }\end{array}$ & $\sim 22$ \\
\hline 10 & Shale, ferruginous in places & $\sim 20$ \\
\hline 11 & Grey-greenish scale & $\sim 8$ \\
\hline
\end{tabular}

river, eastward through this district, cuts its valley through the softer shales leaving spurs of the harder beds abutting on the cultivated land. The hill at Atawani is typical of those spurs. A typical stratigraphic section, which can be found in this part of the Nile valley, could be described from the top to the bottom in Table 1 .

Hydrogeologically, Egypt is located within the arid zone of North Africa, where there are two main fresh water systems: the first is mainly extracted from the River Nile system and the second is the groundwater (Farrag 2005). The groundwater flows and its quality properties may have 
led to many problems in the temple of Horus as previously studied in technical reports by Groundwater Institute (2012). The study proved that the groundwater system in the area is highly influenced by the Nile flow and its interaction with the soil which depends on the hydraulic conductivity and the outcropping present. Thus, when the stable shelf is made by lithified rock material masses like sandstone and limestone, there would be higher hydraulic conductivity due to the presence of fracture. From the geotechnical point of view, when the soil is composed of clayey shales outcrop, the hydraulic conductivity and the interaction between the Nile and groundwater flow in the temple area would be lower. In the study area, groundwater quality is strongly influenced by the minerals of the dominating stones aquifer through recharging of flowed water (Table 2). These quality features characterized by high salinity index led to different deterioration forms. In fact, there are three major sources of water that influenced the area understudy. They are irrigation draining water coming from agricultural activities (from West to East), Domestic wastewater draining coming from surrounding civil

Table 2 Chemical analysis of groundwater inside the temple and in surrounded area $(\mathrm{mg} / \mathrm{l})$

\begin{tabular}{llllll}
\hline Element & Temple well & Well 1 & Well 2 & Well 3 & Well 4 \\
\hline $\mathrm{Ca}^{++}$ & 1.90 & 1.40 & 2.50 & 0.80 & 1.50 \\
$\mathrm{Mg}^{++}$ & 2.90 & 1.20 & 2.20 & 3.50 & 1.50 \\
$\mathrm{Na}^{+}$ & 14.9 & 0.80 & 68.5 & 13.2 & 1.50 \\
$\mathrm{~K}^{+}$ & 1.80 & 0.10 & 2.00 & 1.60 & 0.20 \\
$\mathrm{HCO}_{3}{ }^{-}$ & 7.50 & 2.30 & 13.0 & 6.40 & 3.00 \\
$\mathrm{CO}_{3}{ }^{-}$ & 1.20 & - & 0.20 & 1.60 & 0.60 \\
$\mathrm{Cl}^{-}$ & 7.00 & 0.70 & 49.8 & 6.00 & 1.00 \\
$\mathrm{SO}_{4}{ }^{-}$ & 3.80 & 0.30 & 6.50 & 5.20 & 0.20 \\
$\mathrm{PO}_{4}{ }^{3-}$ & 1.82 & 0.20 & 12.9 & 1.60 & 0.30 \\
$\mathrm{pH}^{E C}$ & 8.80 & 7.60 & 8.70 & 8.60 & 8.40 \\
$\mathrm{TDS}$ & 1966 & 0.00 & 7.00 & 1.00 & 0.00 \\
\hline
\end{tabular}

buildings (from East, North and South), Nile River draining which is sub-parallel with temple direction (Fig. 3a, b).

\section{Deterioration symptoms dominating in the temple}

The negative roles of groundwater affecting Horus Temple could be summarized in two main mechanisms. The first mechanism, related to micro-deterioration symptoms through fracturing, complete disintegration and surface degradation. This mechanism led to wetting most of the temple surfaces especially in winter, forming different salt species which are one of the primary agents in the loss of the built culture heritage and lead to many forms especially in scaling and flaking forms (McCabe et al. 2011; Fig. 4a, b). The second mechanism is attributed to structural problems that led to some aggressive symptoms such as effective cracks and falling down of some stone fragments from the upper lintels of the temple (mostly resulted through indirect effects), in addition to splinters (Fig. 4c). These problems mostly resulted by water movements under the temple foundation (Cardell et al. 2008), rising damp effects occurred when groundwater flowed into the temple structure base through the pore structure (Rirsch and Zhang 2010); in addition, effect of water suction pressure migrating from the building foundations (estimated by 4-5 m from ground surface) through capillary rising (defined by $12.30 \%$ ), water evaporation rate on its wall surface according to the dominating air temperature and relative humidity, finally, effects of seasonal swelling and shrinking of the clay portion of the soil as argued previously by El-Shishtawy et al. (2013).

\section{Sample criteria, analytical methods}

Analytical techniques are mammoth task to better understand cultural heritage artifacts and to improve understanding of their manufacture, their evolution and/or degradation features during time (Boutaine 2006). So the use of many analytical techniques is necessary especially if
Fig. 3 a Hydraulic section in Edfu temple, b Litholographic section in and around Edfu temple
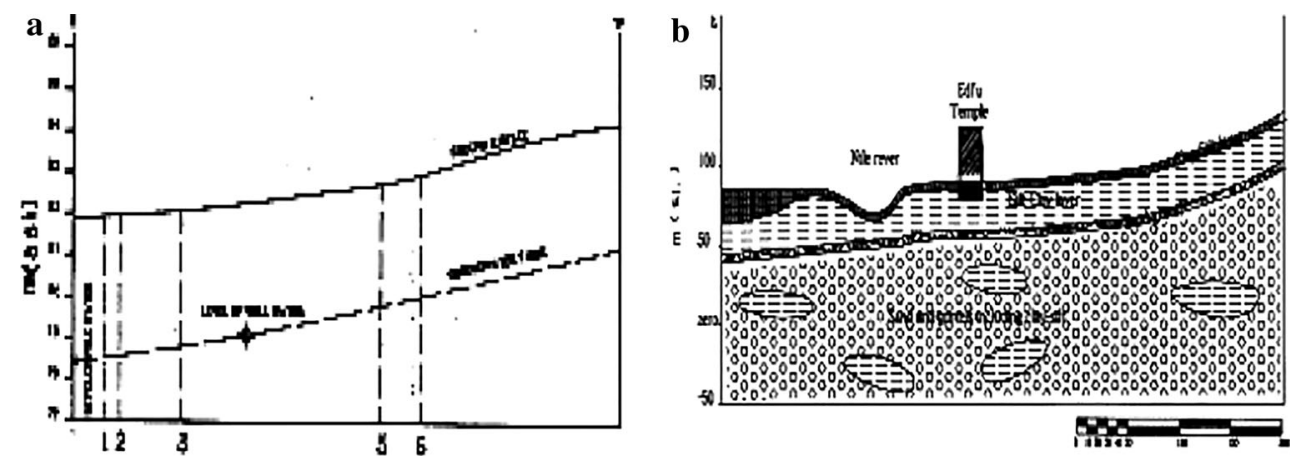

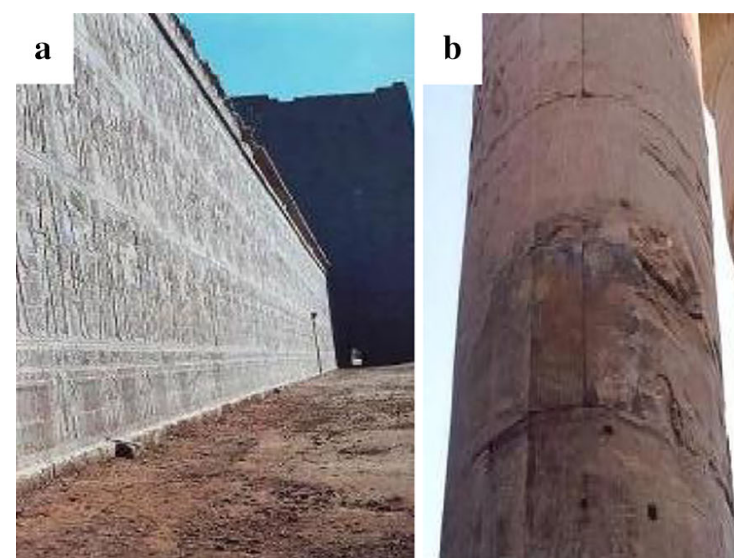

Fig. 4 a Wetting most of the temple surfaces especially in winter in addition to the forming different salt species, $\mathbf{b}$ multi-system of fracturing especially in scaling and flaking forms, c some mechanical

definitive results of the components of cultural heritage are required. From this point of view, a considerable number of these techniques were used to evaluate chemical alterations and different weathering products of the uppermost surface layer or even of microscopic spots in bedrock structure. In addition, other techniques based on differences in physical and chemical properties of water were used for studying natural water composition. From specialized point of view, two types of samples were collected from different locations of the site. The first type represents the groundwater samples which were collected from the well inside the temple, in addition to other four wells outside the temple. These samples were treated and submitted to AAS investigations and chemical titrations according to Hughes et al. (1976) to define the their qualitative and quantitative properties. Furthermore, some water samples were evaporate and fully dried, then analyzed by XRD according to Soukup et al. (2008) to define the relation between the dominated minerals both in the water and the weathering products. In addition, $\mathrm{pH}$, alkalinity (total $\mathrm{mg} / \mathrm{l} \mathrm{CaCO}_{3}$ ), Hardness, TDS $\mathrm{g} / \mathrm{l}$ and EC of the same samples were identified to evaluate the water quality in the study area. The second type of the samples contains micro-samples related to weathering products collected from different directions and heights of the building. They were chosen to reflect the typical weathering features according to their places and they were divided into two categories (light affected areas) (heavy affected areas). According to NORMA (2006) and El-Gohary and Al-Shorman (2010), these samples were studied and analyzed using energy dispersive X-Ray (SEM-EDX) to draw a map of the main types of micro-deterioration morphologies. Moreover, the same samples were quantitatively and qualitatively detected by EDX to define their elemental ratios and kinds, as well as obtaining the relations between the range of stone

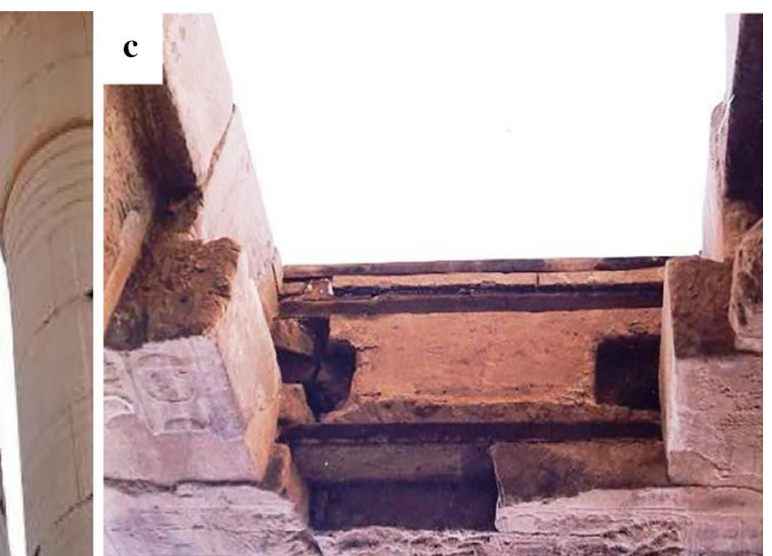

problems in falling down of some stone fragments from the upper lintels of the temple and effective cracks, in addition to splinters

affections (RSA) and the amount of water present (AWP). Furthermore, evaporated groundwater residues were prepared and then analyzed by XRD technique according to Fitzpatrick et al. (2005) for characterizing their mineralogical features using Shimadzu Lab X, XRD 6000 X-Ray Diffractometer.

\section{Results}

\section{Water chemical analysis by AAS}

The analytical results of ground-water samples proved that the chemical constituents are notably varied. These variations are mainly due to the multi-synergetic effects resulting from the combination of dominating salts in the study area. The results of chemical analysis and major properties of samples are listed in Table 3. Moreover, identifying the origin of water (hypothetical salts combination) affirmed that our samples essentially belong to the meteoric water due to the occurrence of carbonates and bicarbonates as major anions. Within the same context, the influence of other minor anions is due to chlorides and sulphates resulted from the human activities (domestic waste water), in addition to phosphate as trace constituents resulting from the effects of cultivation activities. These results are summarized in Table 4.

\section{Morphological description of weathering features}

The morphological features of investigated samples captured by SEM affirmed that the stone was highly influenced by severe groundwater effects and its serious chemical components. Different photomicrographs deal with the presence of weakness and collapsing features, some salt 
Table 3 Chemical analysis and major properties of groundwater samples of Horus temple

Table 4 Hypothetical salts combination of groundwater samples (water origin) of Horus temple

\begin{tabular}{|c|c|c|c|c|}
\hline \multicolumn{3}{|c|}{ Ground water quality $\mathrm{mg} / \mathrm{l}$ major ions } & \multicolumn{2}{|c|}{ Other properties major properties } \\
\hline \multirow[t]{4}{*}{ Cations } & $\mathrm{Ca}^{++}$ & 38.5 & \multicolumn{2}{|l|}{$\mathrm{pH}(8.8)$} \\
\hline & $\mathrm{Mg}^{++}$ & 41.6 & & Alkalinity (2.48) \\
\hline & $\mathrm{Na}+$ & 342.6 & & TH (20.707) \\
\hline & $\mathrm{K}^{+}$ & 69.3 & & TDS. mg/l (1.189) \\
\hline \multirow[t]{5}{*}{ Anions } & $\mathrm{HCO}_{3}{ }^{-}$ & 387.9 & & EC (1966) \\
\hline & $\mathrm{CO}_{3}^{-}$ & 69.00 & & \\
\hline & $\mathrm{Cl}^{-}$ & 248.5 & & \\
\hline & $\mathrm{SO}_{4}^{-}$ & 184.9 & & \\
\hline & $\mathrm{PO}_{4}^{3-}$ & 64.7 & & \\
\hline Family & \multicolumn{2}{|c|}{ Compound name } & Chemical formula & Common name \\
\hline \multirow[t]{6}{*}{ Carbonate and bicarbonate } & \multicolumn{2}{|c|}{ Calcium carbonate } & $\mathrm{CaCO}_{3}$ & Calcite \\
\hline & \multicolumn{2}{|c|}{ Calcium bicarbonate } & $\mathrm{Ca}\left(\mathrm{HCO}_{3}\right)_{2}$ & Calcium bi carbonate \\
\hline & \multicolumn{2}{|c|}{ Magnesium carbonate } & $\mathrm{MgCO}_{3}$ & Magnesite \\
\hline & \multicolumn{2}{|c|}{ Magnesium bicarbonate } & $\mathrm{MgCO}_{3} 3 \mathrm{H}_{2} \mathrm{O}$ & Nesquehonite \\
\hline & \multicolumn{2}{|c|}{ Sodium carbonate } & $\mathrm{Na}_{2} \mathrm{CO}_{3}$ & Natron \\
\hline & \multicolumn{2}{|c|}{ Sodium bicarbonate hydrate } & $\mathrm{Na}_{2} \mathrm{CO}_{3} \cdot 10 \mathrm{H}_{2} \mathrm{O}$ & Baking soda \\
\hline \multirow[t]{2}{*}{ Choloride } & \multicolumn{2}{|c|}{ Sodium Chloride } & $\mathrm{NaCl}$ & Halite \\
\hline & \multicolumn{2}{|c|}{ Potassium Chloride } & $\mathrm{KCl}$ & Sylvite \\
\hline \multirow[t]{2}{*}{ Sulphate } & \multicolumn{2}{|c|}{ Sodium Sulphate } & $\mathrm{Na}_{2} \mathrm{SO}_{4}$ & Thenardite \\
\hline & \multicolumn{2}{|c|}{ Potassium Sulphate } & $\mathrm{K}_{2} \mathrm{SO}_{4}$ & Arcanite \\
\hline \multirow[t]{2}{*}{ Phosphate } & \multicolumn{2}{|c|}{ Hidroxyl-apatite } & $\mathrm{Ca}_{5}\left(\mathrm{PO}_{4}\right)_{3}(\mathrm{OH}, \mathrm{Cl})$ & Hidroxyl-apatite \\
\hline & Chlc & & $\mathrm{Ca}_{5}\left(\mathrm{PO}_{4}\right)_{3} \mathrm{Cl}$ & Chloroapatite \\
\hline
\end{tabular}

species such as sodium sulphate in its complex shape. Moreover, fracture and disintegration form in addition other noticeable symptoms such as disfiguring apparent, cracks, crevices and grains roundness and dissolution phenomena. All of these results are shown in Fig. 5a-f.

\section{Chemical composition of weathering products}

The quantitative and qualitative results made by EDX micro-analysis deal with the samples that were highly affected by different dominating types of salts and other environmental factors. These influences have led to the decreasing of the main components of sandstone 95.11-44.08\% and vice versa increasing the quantities of weathering products from 4.89 to $55.92 \%$. Both the elemental components average of light affected stone (3 samples) and the average of highly affected stone (3 samples) are presented in Table 5 .

\section{Mineralogical analysis of evaporated residues by XRD}

The results of evaporated groundwater residues collected from the study area by XRD attested that the main components of these samples composed essentially of Halite $(\mathrm{NaCl})$, Sylvite $(\mathrm{KCl})$ and Thenardite $\left(\mathrm{Na}_{2} \mathrm{SO}_{4}\right)$ as major salt species in addition to Niter $\left(\mathrm{KNO}_{3}\right)$ and Natron $\left(\mathrm{Na}_{2} \mathrm{CO}_{3}\right)$ as minor salt species (Table 6).

\section{Discussion}

The durability of building materials is an issue with large implications. The most important factor governing this durability is most likely weathering which involves various processes. Subsurface water is often a critical factor in various engineering work, as well as the archaeological buildings; it has shortened the design life of stone structures and contributed to the failure of building settlement and foundations movements (Douglas and Noy 2011). It is well known that groundwater has great effects on rocks strength, where it leads to the growth of salt crystals within pores and can cause internal stresses. Also, it leads to the enhancement of the stone structure collapsing and reducing its strength through several chemical mechanisms such as adsorption-desorption and ion exchange as previously reported by Romijn (2002). For instance, these effects mostly depend on stone physical and mechanical properties 

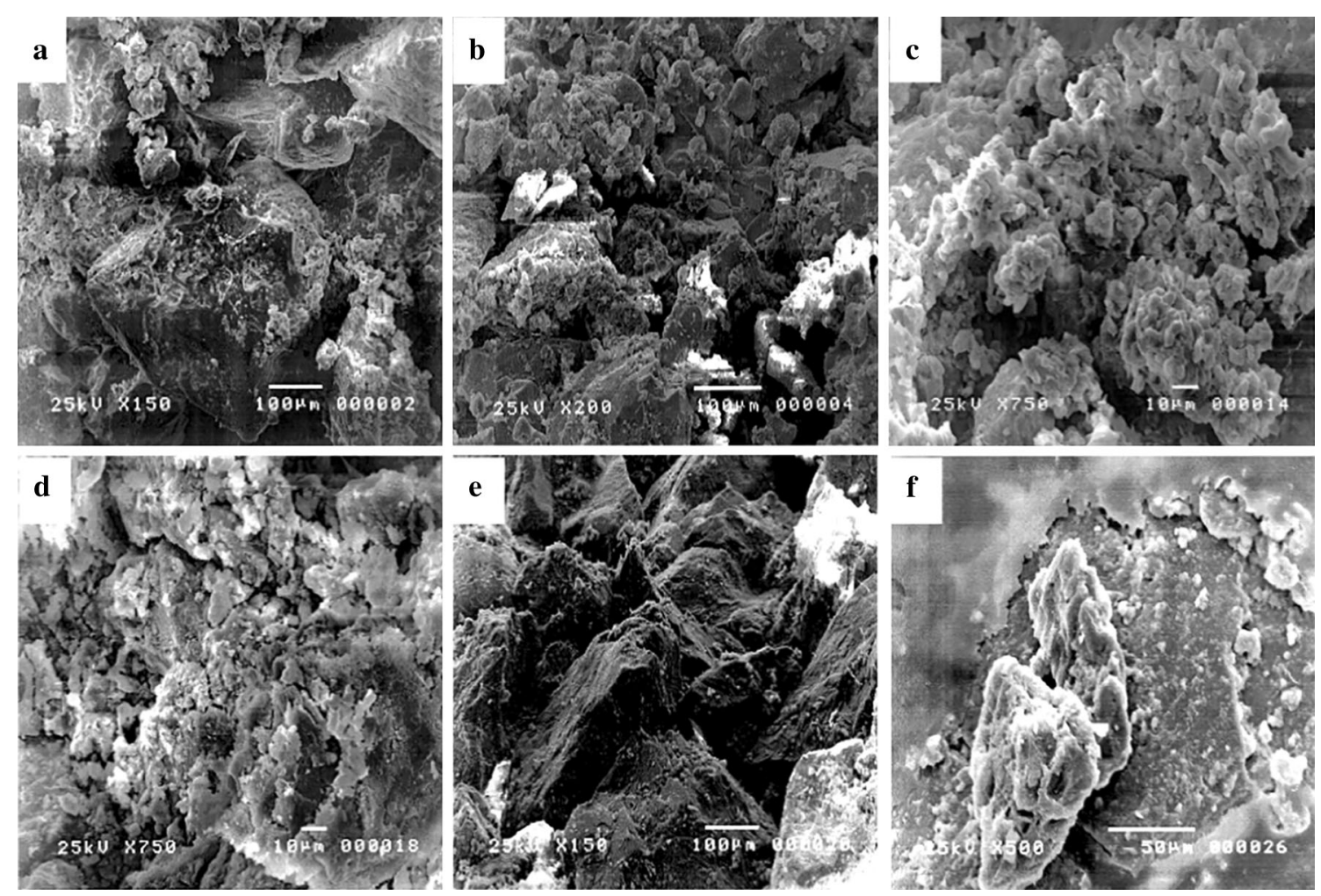

Fig. 5 Photomicrographs show, a weakness and collapsing of quartez grains as a result of drying wetting cycles, X-150, b fracture and disintigration phenomena affacting $\mathrm{qz}$ grains and presence of sylvite salt $\mathrm{KCl}, \mathrm{X}-200$, c sample of sodium sulphste in its complex shape and disfiguring apparent affecting stone surfaces, X-750, $\mathbf{d}$ cracks and crevices resulting from stress and strains inside the stone and spherical gypsum crystals a result of interaction with salinity water and wetting drying cycles, X-750, e weakness and roundness of qz grains as a result weathering processes, dissolution phenomena and presence of $\mathrm{NaCl}$ and developed black crusts, $\mathrm{X}-150$, and $\mathbf{f}$ fracture and dissolution affecting $\mathrm{qz}$ grains as a result of interaction with salinity water, $\mathrm{X}-500$
Table 5 Quantitative and qualitative analysis of weathering products by EDX

\begin{tabular}{lccccccccc}
\hline Samples state & \multicolumn{2}{l}{ Analytical results } & & & & & & & \\
\cline { 2 - 9 } & $\mathrm{Si}$ & $\mathrm{Al}$ & $\mathrm{Fe}$ & $\mathrm{K}$ & $\mathrm{Ca}$ & $\mathrm{Na}$ & $\mathrm{S}$ & $\mathrm{Cl}$ & $\mathrm{Mg}$ \\
\hline Light affected & 82.83 & 4.7 & 1.96 & 0.96 & 4.66 & 0.89 & 0.00 & 4 & - \\
Heavy affected & 6.94 & 14.58 & 0.00 & 16.16 & 6.4 & 7.85 & 0.27 & 44.97 & 2.83
\end{tabular}

Table 6 Main components of evaporated groundwater residues by XRD

\begin{tabular}{llll}
\hline No. & Name & Formula & D spacing by intensity $\left(I / I_{\mathrm{o}}\right)$ \\
\hline 1 & Natron & $\mathrm{Na}_{2} \mathrm{CO}_{3}$ & $2.894,3.015,3.036,5.37$ \\
2 & Halite & $\mathrm{NaCl}$ & $1.62,1.994,2.82,2.84,3.260$ \\
3 & Sylvite & $\mathrm{KCl}$ & $1.816,2.22,3.15$ \\
4 & Thenardite & $\mathrm{Na}_{2} \mathrm{SO}_{4}$ & $1.553,1.841,2.783,3.178,4.66$ \\
5 & Niter & $\mathrm{KNO}_{3}$ & $2.65,3.03,3.73,3.78$ \\
\hline
\end{tabular}

particularly, porosity and permeability. Furthermore, they are related to total dissolved solids (TDS) and different dominating chemical constituents (calcium, magnesium, sodium, potassium, chloride and sulphate), in addition to total hardness $(\mathrm{TH})$ and hydrogen ion concentration $(\mathrm{pH})$.
From a specialized point of view, the groundwater in the study area and its chemical constituents led to the creation of deterioration multi-systems that vary between structural defects and micro-weathering scale. These effects that lead finally to an illness-most commonly a cancer-undermining the health of the building and eventually leading to its demise as mentioned previously by Malaga-Starzee et al. (2000) in similar case. Within the same context, the static groundwater level inside the temple mostly ranged between 3.16 and $3.50 \mathrm{~m}$ from the temple surface. It is mostly influenced by different chemical components coming out from the soil essentially affected by three kinds of drainages that are characterized by having different origins.

The first is irrigation drainage water: this water leaks into the temple from the western side (Fig. 2a). It can play 
a partial harmful role in the degradation processes of not only sandstones, but also the soil under the temple through chemical constituents that contains (phosphates). This type of salt comes from the fertilizer that is mostly used in the surrounding cultivated lands or from the human bones buried near the neighborhood of the temple that contribute to the contamination process. The second is domestic waste water: this type plays an aggressive role in the deterioration processes of the temple; it comes from the civil buildings and houses which encompass the temple from all directions (Fig. 2b). These houses are built on a layer of silt and clay distinguished by a low degree of permeability that is able to keep this water and its chemical constituents such as (sulphate and carbonate salts). These salts have a high ability to make physical and chemical disintegration of stone leading to the absorbing of this water towards the stone causing full deterioration of stones (El-Gohary 2011). The Nile water is the third source of water affecting the temple deterioration, where the temple is about $1100 \mathrm{~m}$ far from the Nile. The field study proved that there is a big chance for water table to rise under the temple especially in the winter, which leads to an increase of the disintegration and decay processes of stones especially with the presence of wastes produced from the paper pulp factory (Awadalla et al. 1995). The chemical constituent of these wastes mostly contains all types of anions that owe to the human different activities (carbonate and bi-carbonate in addition to some trace anions sulphates and chlorides). All the previous sources created through several main deterioration effects which vary from micro-effects of structural defects that are known as main deterioration phenomena caused by groundwater affected Horus temple.

Micro-deterioration forms recorded at the temple might be created through the interaction between different ground water effects (physical and chemical) and other deterioration mechanisms caused by other ambient factors. Physical mechanism appears as a wetting of stone surfaces that mostly occurs with water presence in any of its various forms, which causes and accelerates the decay of most building materials. In our case study, this mechanism resulted through the effects of ground water and led to the presence of stone wetting through water penetration within the stone pores. This complex process finally leads to salt crystallization and consequent physical pressures (Fassina et al. 2012). Chemical mechanism tends to establish equilibrium between temple rocks and dominating environmental factors through weathering process. This type of weathering is mostly enhanced by the movement of groundwater through the networks of discontinuities present in rock masses. In addition, it could be claimed that most of ground waters may be quite polluted by high levels of salt anions such as $\mathrm{HCO}_{3}{ }^{-}, \mathrm{CO}_{3}{ }^{-}, \mathrm{NO}_{3}{ }^{-}, \mathrm{Cl}^{-}$, and $\mathrm{SO}_{4}{ }^{-}$ (Appleo and Postma 2005). In our case these anions

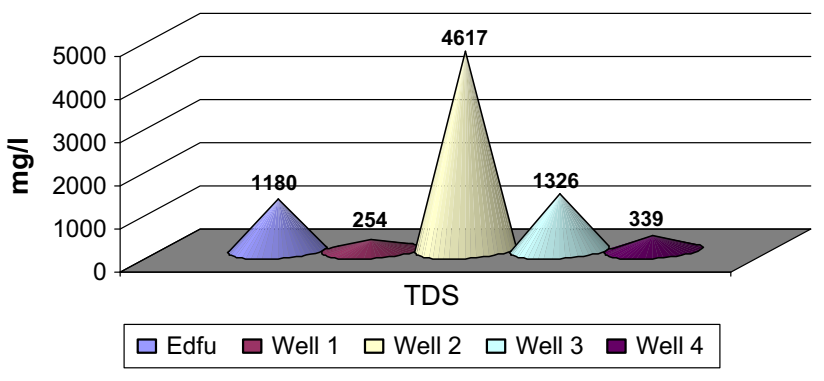

Fig. 6 TDS relations between result of groundwater analysis of Edfu temple well and the wells in surrounded area

resulted from rich chemical compounds that reach the floor and stones under the temple crossing the clay shale layer as represented in Fig. 2c. Within the same context, chemical analyses presented in Table 2 show that there is richness of mineral compounds as their TDS which is quite high (in fact in some sample it is more than $1000 \mathrm{mg} / \mathrm{l}$ ) (Fig. 6). This aggressive percentage creates harsh deterioration mechanisms, these mechanisms and their related forms may be due to two main factors.

The first factor is related to the very low value of pluviometric precipitation in the study area, which in fact means rising in groundwater levels about few millimeters a year. The second one is the richness in the chemical constituents, which is due to the quite long staying of groundwater in the soil as it has to flow across clay layers because of its low hydraulic conductivity. In its slow flowing in the ground, the chemical interaction with rock masses becomes very high, especially with the clay, which is easy to exchange its chemical constituents with groundwater. So, the temple groundwater is relatively rich in $\mathrm{Na}^{+}, \mathrm{Mg}^{2+}$ and $\mathrm{Ca}^{2+}$. In addition, the analysis of groundwater affirmed that it is very mixed with water coming from the human activities this maybe due to high level both of $\mathrm{Cl}^{-}$content and the high presence in $\mathrm{SO}_{4}^{-}$. Thus it could be said that the global effects of these processes are chemically aggressive and can favor the weathering of the temple rock minerals that can lead to many deterioration appearances. The presence of some salt species contributes to the process, such as calcium carbonate, which is a main component resulting from limestone structural geological bed. It does not have by itself a disintegrating effect once it has crystallized, but it forms incrustations that are very hard and intractable. Regarding sodium chloride, it is the most common salt in urban areas (Panno et al. 2006), produced by the solution of halite which leads through hydration and dehydration cycles to promote the deterioration of surfaces by its action on other salts that may be present under the effect of varying temperature (Wells et al. 2006).

Most of these salts are crystallized on building stone surfaces as efflorescence in fine white crystals that lead to 
severe deterioration forms as crusting, black hard crusts and discoloration. Furthermore, the field investigations indicate that the crystallization is also taking place below the surface (sub-efflorescence) (McCabe et al. 2008), which can cause many forms of damage such as stone fracturing, granular disintegration, sugaring and other harmful forms. These forms are mostly due to the intrinsic deterioration factors, particularly expansioncontraction joint. It means a break in a rock produced by mechanical failure and it mostly includes faults and joints (Chacon 1999). Moreover, other deterioration forms were mentioned with minor grade particularly scaling and flecking. According to El-Gohary and Al-Shorman (2010), scaling is a serious physical form, attributed to the sensitivity of stone materials for deterioration processes especially with the presence of some aggressive sources of salts such as halite and sulphate characterizing the ground water in this area. Flaking is a detachment of small, thin stone elements due to the presence of soluble salt and salt crystals that is often attributed to volume expansion accompanying hydration of the anhydrous salts (Pavlík et al. 2013).

Structural problems refer to mechanical damage results by the load or the stress affecting stone structure or those results by the poor design of the buildings (Steiger et al. 2011). Furthermore, the effects of differential soil settlement that cause some cracks in the structures, while catastrophic events such as earthquakes are responsible for heavy damages in buildings. Also, there are many types of structural damages that stones can undergo which may produce particular deterioration patterns that are then described by specific terms. In our case, many problems resulted from some structural defects affecting the temple. These defects are essentially due to the effects of geological and stratigraphical features, in addition to the effects of other underground environment and ground water movements. They are falling down from some stone fragments of the upper lintels of the temple. They are mostly due to the structural behavior of load bearing stone columns of the temple. Moreover, these effects may be due to the problems caused by clays shrinkable and contractible actions that lead to building cracking through charging and discharging the groundwater, particularly near building foundations resulting from water infiltration and re-crystallization phenomena (Mills 2004). Within the same context the effective cracks affected some arches in our case are mostly closely followed the lines of the junctions between the exterior buttresses and the infill panels as argued previously by Blades and Stewart (2004) in his case study. According to Weaver (1997), these cracks are serious forms affecting the archaeological buildings, their effects resulted essentially from corrosion process that caused the ferrous metal to laminate and split the surrounding stones because of the increasing moisture. Regarding splinters, as a structural deterioration form, it is a serious deterioration form resulting essentially from detachment of large compact stone elements (Croci 1998). This mechanism mostly occurs in the splinter shape in irregular fractures across the usual zones of weakness, bedding planes in few centimeters and joints. It means broken stone surfaces to many small fragments, which mostly occur as a direct result of the signature of the crystal wedging process (White and White 2003). Finally, the structural problems and all of accompanying changes mostly result from the increasing material susceptibility to deterioration processes. These changes like iron minerals oxidation, clays hydration and dehydration and quartz expansion or contraction, in addition to dimensional change resulting from thermal cycling.

\section{Conclusion}

The study assessed the evolution of the harmful effects of groundwater in Horus Temple area through estimating its quality, which plays an important role in the weathering processes affecting the temple area through two main mechanisms (micro-deterioration and structural defects). This research also has led to some core parameters and findings that explained the aggressive effects of groundwater on the decay of monumental buildings, in addition to other parameters influencing deterioration like $\mathrm{pH}$, TDS, alkalinity, TH and EC. In collating the results obtained by AAS analysis and micro-morphological studies made by SEM analysis, we can indicate definitely that diverse deterioration processes operate synergistically on temple building materials leading to the mentioned weathering patterns (surfaces wetting, forming of salt species, presence of fracturing multi-system especially in scaling and flecking, falling down of some stone fragments, and effective cracks and splinters). A conservation policy for our case study exposed that this aggressive environment can be established by improving routine maintenance practices. It should include some scientific procedures that vary from interventive actions (salt extraction procedures followed by right consolidation and protection steps according to the material types) to preventive procedures (improving the quality and quantity of groundwater through good and accurate hydro-geochemical studies). Finally, for structural conservation, it aims at evaluating a suitable systematic approach for developing general criteria of compatibility in selecting the replacement materials for disintegrated and missing parts in the monuments that comprise more than one natural building stone material. 
Open Access This article is distributed under the terms of the Creative Commons Attribution 4.0 International License (http://crea tivecommons.org/licenses/by/4.0/), which permits unrestricted use, distribution, and reproduction in any medium, provided you give appropriate credit to the original author(s) and the source, provide a link to the Creative Commons license, and indicate if changes were made.

\section{References}

Appleo C, Postma D (2005) Geochemistry groundwater and pollution, 2nd edn. Balkema Publisher, Leiden

Awadalla R, Soltan M, Ali M, Rashed M (1995) Influence of a paper pulp factory's effluent on the River Nile water quality. In: Assiute Univ. (eds.), 1st Int. conf. on the environment \& development in Africa Assiute Univ., Assiute, Egypt, pp 1-7

Baines J, Malek J (2000) Atlas of ancient Egypt, Revised edn. Checkmark Books, Oxford

Beaty R, Kerber J (1993) Concepts, instrumentation and techniques in atomic absorption spectrophotometry, 2nd edn. The PerkinElmer Corporation Norwalk CT, USA

Blades K, Stewart J (2004) The repair and remedial treatment of the east block parliament buildings. In: Ashurst J, Dimes F (eds) Conservation of building and decorative stone, vol 2. Elsevier, Amsterdam, pp 114-124

Boutaine JL (2006) The modern museum, Ch. 1. In: Bradley D, Creagh D (eds) Physical techniques in the study of art, archaeology and cultural heritage. Elsevier, Amsterdam, pp 1-50

Cardell C, Benavente D, Rodríguez-Gordillo J (2008) Weathering of limestone building material by mixed sulfate solutions. Characterization of stone microstructure, reaction products and decay forms. Mater Charact 59:1371-1385

Cardell C, Yebra A, Van Grieken R (2002) Applying digital image processing to SEM-EDS and BSE images to determine and quantify porosity and salts with depth in porous media. Microchim Acta 140(1-2):9-14

Chacon M (1999) Architectural stones, fabrication, installation and selection. Wiley, NY

Croci G (1998) The conservation and structural restoration of architectural heritage. WIT Press, London

Douglas J, Noy E (2011) Building surveys and reports: foundation failures Ch. 5, 4th ed. Wiley-Blackwell, UK

El-Gohary M (2011) Chemical deterioration of Egyptian limestone affected by saline water. IJCS 2(1):17-28

El-Gohary M (2012) Behavior of treated and un-treated lime mortar before and after artificial weathering. Int J Restor Build Monum 18(6):369-380

El-Gohary M, Al-Shorman A (2010) The impact of the climatic conditions on the decaying of Jordanian basalt: exfoliation as a major deterioration symptom. Int $\mathrm{J}$ Archaeol Archaeom 10(1):143-158

El-Shishtawy A, Atwia M, El-Gohary A, Parizek R (2013) Impact of soil and groundwater corrosion on the Hierakonpolis temple town archaeological site, Wadi Abu Sufian, Idfu, Egypt. Environ Monit Assess 185:4491-4511

Farrag A (2005) The hydraulic and hydrochemical impacts of the Nile system on the groundwater in upper Egypt. Assute Univ Bull Environ Res 8(1):87-102

Fassina V, Fumo G, Cornale P (2012) Condition assessment of the marble funerary monument to Antonio Canova in the basilica dei Frari in Venice: A new mechanisms of marble decay, preprint of the proceeding of 12 th Int. cong. on the deterioration and conservation of stone, NY, p 10
Fitzpatrick M, Fry A, Holdway P, Kandil F, Shackleton J, Suominen L (2005) Determination of residual stresses by X-ray diffraction-issue 2. Measurement good practice guide No. 52, p 77

Freestone I, Middleton A (1987) Mineralogical applications of the analytical SEM in archaeology. Mineral Mag 51:21-31

Hughes M, Cowell M, Craddock P (1976) Atomic absorption techniques in archaeology. Archaeometry 18(1):19-37

Institute Groundwater (2012) Database 1997-2010. Edfu unit, Egypt

Kim K (2002) Plagioclase weathering in the groundwater system of a sandy silicate aquifer. Hydrol Process 16:1793-1806

Kim K, Rajmohan N, Kim H, Kim S, Hwang G, Yun S, Gu B, Cho M, Lee $S$ (2005) Evaluation of geochemical processes affecting groundwater chemistry based on mass balance approach: a case study in Namwon, Korea. Geochem J 39:357-369

Linnow K. (2007) Salt damage in porous materials: an RH-XRD investigation $\mathrm{PhD}$, Department Chemie der Fakultät für Mathematik, Info rmatik und Naturwissenschaften, Universität Hamburg von aus Hamburg

Malaga-Starzee K, Shalin T, Lindqvist O (2000) Laboratory investigation of weathering behavior of fresh and impregnated limestone and sandstone from central Sweden. In: Fassina V (ed.) 9th Int. cong. on deterioration and conservation of stone Vol. I, Elsevier, Venice, pp 349-356

McCabe S, McKinley J, Smith B (2008) Simulating initial stages of salt accumilation and organisation within building sandstones. In: Lukszewicz J, Niemcewicz $\mathrm{P}$ (eds.) 11th Int. cong. on deterioration and conservation of stone. Nicholas Copernicus University, Torun Poland, pp 173-180

McCabe S, Smith B, McAllister J, McAllister D, Srinivasan S, Basheer P, Curran J (2011) Linking climate change, moisture dynamics and salt movement within natural building sandstones: implications for salt transport by diffusion. In: Theodoridou M (ed) Ioannou I. SWBSS, Limassol, pp 63-70

Mills R (2004) Structural failure and repair. In: Ashurst J, Dimes F (eds) Conservation of building and decorative stone, vol 2. Elsevier, Amsterdam, pp 55-70

Molina Ballesteros E, Cantano Martín M, García Talegón J (2010) Role of porosity in rock weathering processes: a theoretical approach. Cadernos Lab. Xeolóxico de Laxe Coruña 35:147-162

Montoto M (2000) Advances and problems in techniques and methodologies for degradation diagnosis in stone conservation. In: Galán E, Zezza F (eds) Protection and conservation of the cultural heritage of the Mediterranean cites. Taylor \& Francis, Sevilla, pp 10-14

NORMA UNI-11182 (2006) Beni culturali-Materiali lapidei naturali ed artificiali- Descrizione della forma di alterazione-Termini e definizioni. (ente nazionale italiano unificazione), Milano

Panno S, Hackley K, Hwang H, Greenberg S, Krapac I, Landsberger S, O'Kelly D (2006) Characterization and identification of Na$\mathrm{Cl}$ sources in ground water. Groundwater 44(2):176-187

Pavlík Z, Žumár J, Pavlíková M, Černý R (2013) Interaction of building stones with inorganic water-soluble salts. World Acad Sci Eng Technol 7:131-136

Rirsch E, Zhang Z (2010) Rising damp in masonry walls and the importance of mortar properties. Constr Build Mater 24:1815-1820

Romijn E (2002) Groundwater quality and contamination. In: Zaporozec A (ed) Groundwater contamination inventory. A methodological guide. IHP-VI, series on groundwater, No 2 . UNESCO, pp 17-22

Senosy M, Felesteen A, Hamdan A (1998) Application of electrical resistivity method in ground water elevation of Wadi El-Sa'ayda area, northwest of Idfu. Egypt Bull Fac Sci Assiut Univ 27(2):121-145 
Soukup D, Buck B, Harris W (2008) Preparing soils for mineralogical analyses, Ch 2. In Methods of Soil Analysis. Part 5. Mineralogical Methods. SSSA Book Series, no. 5, pp 13-31

Steiger M, Elena Charola A, Sterflinger K (2011) Weathering and deterioration Ch. 4. In: Siegesmund S, Snethlage R (eds) Stone in architecture. Springer-Verlag, Berlin, pp 227-316

Turkington A, Smith B (2000) Observation of three-dimensional salt distribution in building sandstone. Earth Surf Process Landforms 25:1317-1332

Weaver M (1997) Conserving buildings: Guide to techniques and materials. Wiley, NY
Wells T, Binning P, Willgoose G, Hancock G (2006) Laboratory simulation of the salt weathering of schist: 1 . weathering of schist blocks in a seasonally wet tropical environment Earth Surf Process Landforms 31:339-354

White W, White E (2003) Gypsum wedging and cavern breakdown, studies in the Mammoth cave system, Kentucky. Natl Speleol Soc J Cave Karst Stud 65(1):43-52 